\title{
Growth dynamics of marine Synechococcus spp. in the Gulf of Alaska
}

\author{
Susanne Neuer* \\ School of Oceanography, WB-10, University of Washington, Seattle, Washington 98195, USA
}

\begin{abstract}
Abundance, specific growth rates and overall contribution to phytoplankton carbon and productivity of marine Synechococcus spp. were investigated in the Subarctic Pacific during SUPERcruises III and IV in June and September 1987. Specific growth rates of the cyanobacteria were measured by the frequency-of-dividing-cells method. Vertical distribution of Synechococcus spp. varied seasonally, with cells evenly distributed in the mixed layer at the beginning of June, but concentrated in and below the pycnocline $(40$ to $60 \mathrm{~m}$ ) in September. Laboratory experiments on strains isolated from the Gulf of Alaska indicate a duration of division of $10.5 \mathrm{~h}$. The calculated instantaneous growth rate was maximum in June at the surface $\left(0.7 \mathrm{~d}^{-1}\right.$ ), but much lower in September in the mixed layer (about $0.25 \mathrm{~d}^{-1}$ ) and lowest below the pycnocline (about $0.16 \mathrm{~d}^{-1}$ ). In June near the surface, the contribution of Synechococcus spp. to phytoplankton carbon and total primary production was estimated to be 21 and $8 \%$, respectively. The contribution was lower in September in the surface but increasing with depth reaching maximum values at and below the $1 \%$ light level (50 to $60 \mathrm{~m}$ depth) of 31 and $68 \%$, respectively. Growth rates determined in the field, as well as in the laboratory, are in the range of values found for Synechococcus spp. populations thriving at lower latitudes, indicating that the low temperatures of the Subarctic Pacific do not inhibit growth of Synechococcus spp.
\end{abstract}

\section{INTRODUCTION}

As much as one third of the global plant production may be due to picoplankton (cells $<3 \mu \mathrm{m}$ ), with more than half of this production attributed to the cyanobacteria of the Synechococcus group (Bolin et al. 1977, Li et al. 1983, Shapiro \& Guillard 1986). Since the discovery of marine Synechococcus spp. more than $10 \mathrm{yr}$ ago (Waterbury et al. 1979, Johnson \& Sieburth 1979), many workers have been concerned with assessing the abundance and productivity of these cells in the field as well as the requirements for growth in laboratory studies. Most of the previous work has been done in oceans of lower latitudes or on clones isolated from there (see Waterbury et al. 1986 for a review); subpolar oceans such as the North Pacific have received little attention, and information on the growth dynamics of Synechococcus spp, in these waters is lacking.

At the former Ocean Weather Station $P$ in the Gulf of Alaska $\left(50^{\circ} \mathrm{N}, 145^{\circ} \mathrm{W}\right)$ and Station $\mathrm{R}\left(53^{\circ} \mathrm{N}, 145^{\circ} \mathrm{W}\right)$, the temperatures in the mixed layer lie between 6 and

- Present address: College of Oceanography, Oregon State University, Corvallis, Oregon 97331, USA $7^{\circ} \mathrm{C}$ in spring and between 12 and $13^{\circ} \mathrm{C}$ in summer (data from SUPER - Subarctic Pacific Ecosystem Research - cruises in May and August 1984). Macronutrients never fall to concentrations limiting for phytoplankton growth, although the chlorophyll levels are always low, typically 0.3 to $0.5 \mu \mathrm{g} \mathrm{Chl} \mathrm{a} \mathrm{l}^{-1}$ (Frost 1987, Booth 1988). The low plant biomass as well as the absence of a spring bloom is attributed to the balanced trophic relationships prevailing in the Subarctic Pacific (Frost 1987). Alternatively, Martin et al. (1989) suggest that the phytoplankton community in the Subarctic Pacific might be iron-limited (see Banse 1991 and Miller et âl. 1991 for a critical discussion).

The marine Synechococcus group is abundant both in oceanic and neritic environments and represents a cluster of different strains which span a wide range of DNA-base compositions. The marine Synechococcus spp. group has recently been split into 3 clusters (Castenholz \& Waterbury 1989) and most of the open ocean strains have been assigned to the 'marine cluster $\mathrm{A}$ '. This cluster is characterized by having phycoerythrin as its major light harvesting pigment, and a DNA base pair composition that ranges from 55 to $62 \mathrm{~mol} \% \mathrm{G}+$ $\mathrm{C}$. The genetic relatedness of the open ocean strains is 
also supported by DNA hybridization experiments (Douglas \& Carr 1988).

Strains of the marine Synechococcus spp. investigated so far require temperatures above $15^{\circ} \mathrm{C}$ for growth (Campbell \& Carpenter 1986a, Waterbury et al. 1986). Although the group is abundant in the Gulf of Alaska (Booth 1988), it was speculated that the low temperatures prevailing in the northern North Pacific could be a major factor affecting its growth rate (Booth et al. 1988). The principal goal of this study was to assess the in situ growth rate of Synechococcus spp. in the Gulf of Alaska during SUPER cruises III and IV (Jun and Sep 1987) as a function of depth and to determine its overall contribution to total phytoplankton production.

A common way of estimating the growth rate of Synechococcus spp. in the field is size fractionated ${ }^{14} \mathrm{C}$ incubation. The fraction containing Synechococcus spp., however, may also contain other phytosynthetic picoplankton which leads to overestimation of production related to Synechococcus spp. Iturriaga \& Marra (1988) found Synechococcus spp. seemingly growing twice as fast by size fractionated ${ }^{14} \mathrm{C}$ incubation as by micro-autoradiography (Table 4). To arrive at a species-specific estimate of growth of the Synechococcus spp., I applied the frequency-of-dividing cells (FDC) method which has significant advantages over ${ }^{14} \mathrm{C}$-incubation experiments since it does not require experimental manipulations such as incubation and works on a single cell basis (Campbell \& Carpenter 1986a).

\section{MATERIALS AND METHODS}

Field sampling and cell counting. One set of surface (bucket) samples was collected during the 'SUPER-III' cruise in June 1987 at Station R in $2 \mathrm{~h}$ intervals for $1.5 \mathrm{~d}$. An aliquot of $50 \mathrm{ml}$ was fixed with glutaraldehyde (final concentration $1 \%$ ), filtered on a black $0.2 \mu \mathrm{m}$ Nuclepore polycarbonate filter and stored frozen in immersion-oil $\left(<-20^{\circ} \mathrm{C}\right.$; Booth 1987). This set of samples was made available by B. C. Booth (Univ. of Washington) and offered the possibility to compare growth rates in the surface waters during the SUPER cruises in June and September, 1987.

During 'SUPER-IV' in September 1987, 3 diel cycles were sampled, the first at Station R (Sep 17, 01:30 until 21:00 h), the second and third at Station P (Sep 23, 10:30 h until Sep 24,06.00 h and Sep 29, 01:00 h until 21:30 h). Samples were drawn at closely spaced depths in the mixed layer, and at and below the pycnocline (between 40 and $60 \mathrm{~m}$ depth) in 3 intervals. Aliquots of $30 \mathrm{ml}$ were fixed with glutaraldehyde, stained with DAPI (Porter \& Feig 1980) and treated as described above.
Cells were counted using epifluorescence microscopy (Zeiss filter sets \# 487702 [UV-excitation], \# 487705 [blue-light excitation] and \# 487714 [greenlight excitation]). On every slide, 3 groups of ca 100 Synechococcus cells each were enumerated and the percentage of dividing cells determined. A cell was considered dividing when a cell wall constriction was visible. From selected profiles, autotrophic and heterotrophic eukaryotic ultraplankton (cells $<20 \mu \mathrm{m}$ ) were counted on each slide as well. These counts were used to investigate differences in vertical distribution between Synechococcus spp. and other ultraplankton.

To test for the significance of a recognizable diel pattern in the frequency of dividing cells, the daily minimum of dividing cells at the beginning of the light period was compared with the highest frequency of dividing cells at the onset of the dark period using the 2 -sample test for binomial proportions (after Fleiss 1981).

Culture experiments. An enrichment culture of Synechococcus spp. from the Gulf of Alaska was purified using the eukaryotic inhibitor cycloheximide (50 $\mathrm{mg} \mathrm{l}^{-1}$ ). The enrichment medium was inoculated from a sample taken from $60 \mathrm{~m}$ depth at Station $\mathrm{P}$ on October 3, 1987 and grown for several months at $13{ }^{\circ} \mathrm{C}$, 40 to $50 \mu \mathrm{mol}$ photons $\mathrm{m}^{-2} \mathrm{~s}^{-1}$ continuous light in BG11 medium (Rippka et al. 1979, with 'Instant Ocean' artifical seawater substituted for distilled water; R. W. Castenholz, Univ. of Oregon, pers. comm.). Until now, neither dilution series nor plates were sucessful in establishing monoclonal, axenic cultures. Thus, the Synechococcus spp. cultured might consist of more than one strain.

The stock cultures were held at $13^{\circ} \mathrm{C}, 25$ to $40 \mu \mathrm{mol}$ photons $\mathrm{m}^{-2} \mathrm{~s}^{-1}$ cool-white fluorescent light in $0.2 \mathrm{~km}$ sterile-filtered SNAX-medium (after Waterbury et al. 1986), in a 15:9 light-dark cycle. Since recontamination by heterotrophic nanoflagellates did occur (possible source: 'sterile-filtered' seawater), cycloheximide was added regularly to the medium. Control experiments showed that the Synechococcus spp. growth rate was not affected by cycloheximide (see also Campbell \& Carpenter 1986b).

Frequency of dividing cells method. Originally proposed by Hagstrom et al. (1979) for the determination of microbial growth rates, the FDC-approach was first used by Campbell \& Carpenter (1986a) for Synechococcus spp. Given the duration of division under in situ conditions, the growth rate of the cells can be calculated by summing over the fractions of dividing cells in a population taken at subsequent time points which are equal or shorter than the duration of division. McDuff \& Chisholm (1982) reviewed this technique for eukaryotic phytoplankton and proposed the following equation for non steady-state cultures: 


$$
\mu=\left(1 / n t_{d}\right) \sum_{i=1}^{n} \ln \left(1+f_{i}\right)
$$

The equation allows to approximate the average instantaneous population growth rate $\mu\left(\mathrm{d}^{-1}\right)$ from the fraction of cells recognized as undergoing division $\left(\mathrm{f}_{\mathrm{i}}\right)_{\text {; }}$ $\mathrm{n}=$ number of evenly spaced samples taken during one diel cycle; $t_{d}=$ duration of division.

The accuracy in calculating $\mu$ is dependent on a reasonable estimate of $t_{d}$. It has to be known for the strain(s) found and under the in situ conditions prevailing in the field during the time the samples were collected (Chisholm et al. 1986). To find $t_{d}$, the strain(s) of Synechococcus spp. isolated from the Gulf of Alaska were grown at 13 and $8{ }^{\circ} \mathrm{C}$ at irradiances approximating field conditions (Table 2) in a 15:9 h light:dark cycle for several weeks. Growth was monitored using an EPICS V Flow Cytometer (488 nm excitationwavelength). Samples were taken during the exponential growth phase at $2 \mathrm{~h}$ intervals over one diel cycle, fixed with glutaraldehyde and immediately filtered on black Nuclepore filters. Cell numbers and the fraction of dividing cells were determined in each sample as described for the field samples. The instantaneous growth rate of the culture was calculated from the initial and final cell numbers using the exponential growth equation. The duration of division was obtained by solving Eq. (1) for $t_{d}$ using the growth rate and the sum of $\ln \left(1+\mathrm{f}_{\mathrm{i}}\right)$.

Furthermore, the following assumptions underlying the FDC-method were made (see also 'Discussion'): (1) all cells in the population are active, (2) duration of division is the same for all cells in the population, (3) grazing pressure on dividing and on single cells is equal.

The rate of production ( $P, \mu g \mathrm{C}^{-1} \mathrm{~d}^{-1}$ ) of the Synechococcus spp. was calculated according to:

$$
P=1 / t C_{0}\left(e^{\mu t}-1\right)
$$

where $\mu\left(d^{-1}\right)=$ instantaneous growth rate calculated by the FDC-method; $\mathrm{C}_{0}=$ average cell number of the respective diel cycle multiplied by an average carbon content per cell of $0.29 \mathrm{pg} \mathrm{C}$ cell ${ }^{-1}$. Taken from Cuhel \& Waterbury (1984), this value was chosen in order to be consistent with the phytoplankton biomass studies by B. C. Booth within the SUPER project.

Data on total phytoplankton. Data on the rate of total primary production during SUPER-III and SUPER-IV and light data were provided by N. A. Welshmeyer (Moss Landing Marine Laboratories). The uptake studies were conducted as in situ or on-deck incubations over 24 or $48 \mathrm{~h}$. Data on overall phytoplankton carbon were assessed by B. C. Booth (University of Washington) from epifluorescence and light microscopy. Growth rates of total phytoplankton were calcu- lated after the equation given in Booth et al. (1988) Data on phytoplankton carbon and primary production of total phytoplankton were taken from June 21 (June 22 not available) and in September from 3 stations close to the 3 daily cycles sampled (Sep 17, Sep 25-26 and Sep 28).

\section{RESULTS}

\section{Characterization of Subarctic Synechococcus strains}

The strains investigated were unicellular, coccoid and 1 to $2 \mathrm{~m}$ in size, dividing by binary fission in one plane. This morphological description fits the genus Synechococcus (Cyanobacteria) sensu Rippka et al. (1979). Results of epifluorescence microscopy of field samples and of cultures as well as preliminary spectrofluorometric measurements of cultured cells indicate that they possess phycoerythrin, containing both phycoerythrobilin and phycouribilin chromophores. This places this strain under the 'marine cluster A' as defined in Castenholz \& Waterbury (1989).

\section{Field observations}

In June 1987 at Station $R$, the surface temperatures were about $8^{\circ} \mathrm{C}$. The mixed layer was around $30 \mathrm{~m}$ deep and the seasonal thermocline not very pronounced. The water column in September 1987, however, exhibited a strong thermocline around $50 \mathrm{~m}$ depth (Fig. 1a) with the water temperatures around $12^{\circ} \mathrm{C}$ in the mixed layer, decreasing to 7 to $8^{\circ} \mathrm{C}$ in the pycnocline. As shown in Fig. $2 \mathrm{a}$, the depth of the thermocline fluctuated strongly in all 3 diel cycles in September, both at Station R (Sep 17) and Station P (Sep 23-24 and 29), due to internal waves, which offset the pycnocline up to $15 \mathrm{~m}$.

Cell numbers of Synechococcus spp. were ca $1 \times 10^{4}$ cells $\mathrm{ml}^{-1}$ in June at Station R in the surface (Fig. 3) whereas in September the abundance was much lower (ca 0.2 to $0.5 \times 10^{4} \mathrm{ml}^{-1}$, both Stations $\mathrm{P}$ and $\mathrm{R}$; Table 1) in the mixed layer but exhibited a strong peak below the pycnocline at Station $\mathrm{P}$ with up to $2.4 \times 10^{4}$ cells $\mathrm{ml}^{-1}$ (Figs. 1, 2b). Fig. 1b further demonstrates that neither autotrophic nor heterotrophic ultraplankton accumulated at or below the pycnocline. At this station, the cyanobacteria constituted $86 \%$ in cell number of the total photosynthetic ultraplankton. Note that the fluorescence profile did not reflect the cell maximum. At Station R on Sep 17, highest cell numbers were observed in the pycnocline, but reached a maximum of only about $1 \times 10^{4}$ cells ml ${ }^{-1}$ (Fig. 2b). In early June of the same year, the cyanobacteria were evenly distrib- 

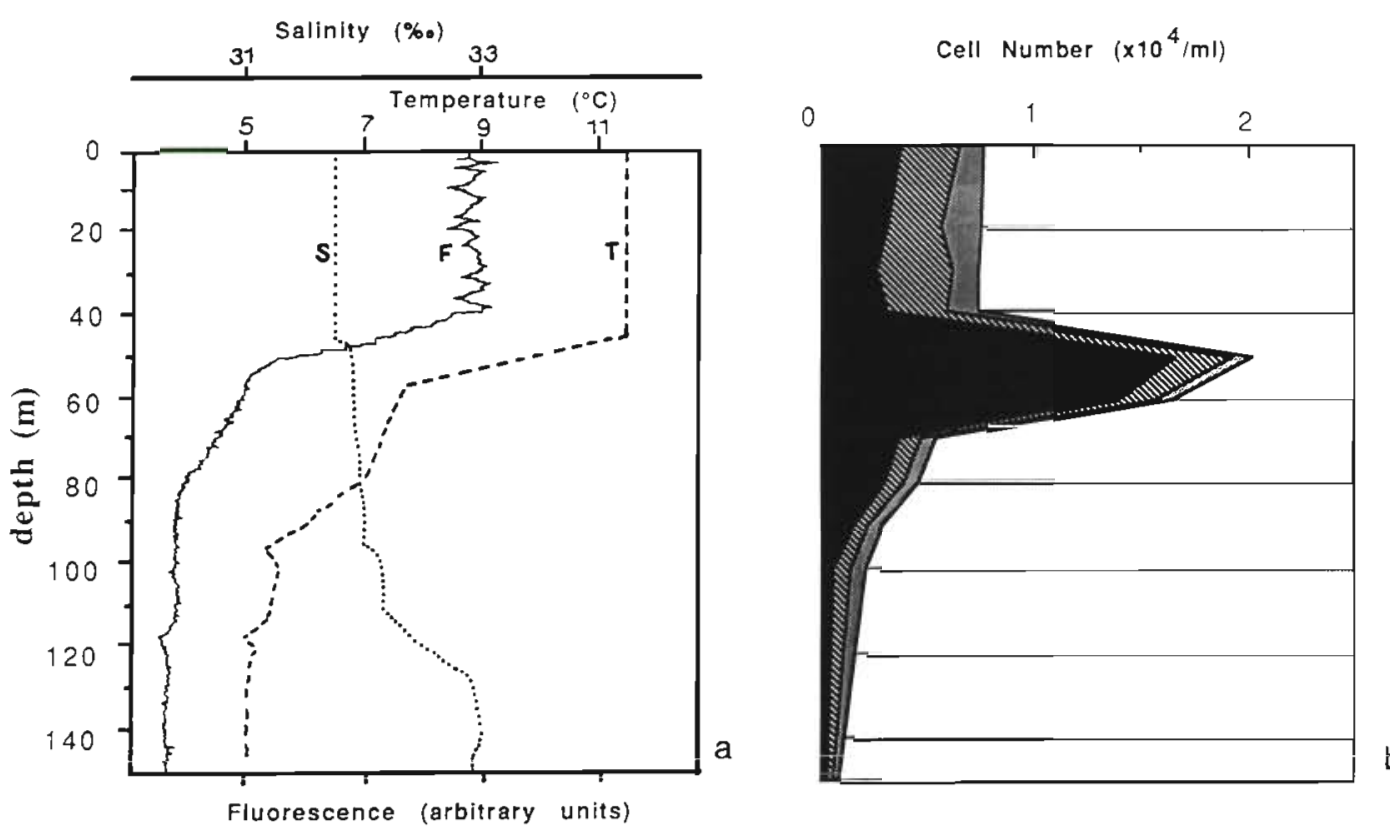

Fig. 1 Station profiles. (a) Vertical profile of temperature, salinity and fluorescence; Station P, Sep 29, 1987, 01:30 h local time. (b) Vertical profile of cell numbers (additıve) of Synechococcus spp. (black); eukaryotıc autotrophic (hatched); eukaryotic heterotrophic (dotted) ultraplankton; Station P, Sep 29, 1987, 01:30 h local time

Table 1. Synechococcus spp. Summary of cell numbers and FDC (each averaged over one diel cycle), and growth rates of all diel cycles sampled in Jun and Sep 1987. The p-value refers to the significance of a diel pattern of FDC when observed (see text); 'no' indicates no pattern

\begin{tabular}{|c|c|c|c|c|c|c|}
\hline Date & Station & Depth & $\begin{array}{c}\text { Cells } \times 10^{4} \\
\left(\mathrm{ml}^{-1}\right)\end{array}$ & FDC & $\mathrm{p}$ & $\stackrel{\mu}{\mu}\left(d^{-1}\right)$ \\
\hline Jun 21 & $\mathrm{R}$ & surface & 1.38 & 0.26 & no & 0.57 \\
\hline Jun 22 & $\mathrm{R}$ & surface & 1.18 & 0.38 & no & 0.78 \\
\hline \multirow[t]{6}{*}{ Sep 17} & $\mathrm{R}$ & surface & 0.47 & 0.11 & $<0.01$ & 0.24 \\
\hline & & $10 \mathrm{~m}$ & 0.55 & 0.12 & $<0.001$ & 0.25 \\
\hline & & $20 \mathrm{~m}$ & 0.44 & 0.12 & $<0.01$ & 0.25 \\
\hline & & $40 \mathrm{~m}$ & 0.57 & 010 & $<0.01$ & 0.21 \\
\hline & & $50 \mathrm{~m}$ & 0.79 & 0.10 & $<0.05$ & 0.21 \\
\hline & & $70 \mathrm{~m}$ & 0.54 & 0.07 & no & 0.14 \\
\hline \multirow[t]{8}{*}{ Sep 23} & $\mathrm{P}$ & surface & 0.36 & 0.12 & $<0.001$ & 0.24 \\
\hline & & $10 \mathrm{~m}$ & 0.32 & 0.11 & $=0.01$ & 0.21 \\
\hline & & $20 \mathrm{~m}$ & 0.28 & 0.11 & $<0.001$ & 0.21 \\
\hline & & $30 \mathrm{~m}$ & 0.29 & 0.11 & $<0.01$ & 0.21 \\
\hline & & $40 \mathrm{~m}$ & 0.50 & 0.10 & $>0.05$ & 0.19 \\
\hline & & $50 \mathrm{~m}$ & 1.47 & 0.07 & $>0.05$ & 0.15 \\
\hline & & $60 \mathrm{~m}$ & 1.49 & 0.08 & $>0.05$ & 0.15 \\
\hline & & $70 \mathrm{~m}$ & 0.99 & 0.10 & no & 0.19 \\
\hline \multirow[t]{6}{*}{ Sep 29} & $P$ & surface & 0.20 & 014 & $<0.001$ & 0.27 \\
\hline & & $30 \mathrm{~m}$ & 0.20 & 0.14 & $<0.001$ & 0.27 \\
\hline & & $40 \mathrm{~m}$ & 0.48 & 0.08 & no & 0.16 \\
\hline & & $50 \mathrm{~m}$ & 1.18 & 0.08 & no & 0.17 \\
\hline & & $60 \mathrm{~m}$ & 1.37 & 0.08 & no & 0.17 \\
\hline & & $70 \mathrm{~m}$ & 0.60 & 0.08 & $<0.05$ & 0.17 \\
\hline
\end{tabular}

uted in the mixed layer, but an accumulation of cells was observed at the end of June at Station $\mathrm{R}$ with up to $6 \times 10^{4}$ cells $\mathrm{ml}^{-1}$ (B. Booth unpubl.).

Cell numbers found at the depth of the pycnocline varied concomitantly with the internal waves migrating through the pycnocline in September (Figs. 2a, b). Cells living at around $40 \mathrm{~m}$ depth seem to have been elevated up to $15 \mathrm{~m}$ for ca $4 \mathrm{~h}$ once to twice per day. The incident light intensity for these populations must have increased approximately 10 -fold at the wave crest. Fahnenstiel et al. (1988) found that the increased irradiance received by oscillating communities results in an increased production, if the amplitude of the wave is $>5 \mathrm{~m}$ and the community lives at low irradiance. Both conditions are true in this case.

Other than the fluctuations induced by the internal waves, no consistent pattern of increase or decrease in cell number could be observed either in September in the mixed layer or in June in surface waters.

The frequency of dividing cells (FDC) and the diel change of frequency of dividing cells were different between June and September. In June (Fig. 3), the FDC was high and increased throughout the investigation period (average of 0.26 on Jun 21 and 0.38 on Jun 22; Table 1). Campbell \& Carpenter (1986a) observed that the FDC of Synechococcus spp. in the surface at a Sargasso Sea station was higher on sunny and calm than on stormy days. But since light data prior to June 21 are not complete, it is not clear whether the increase 

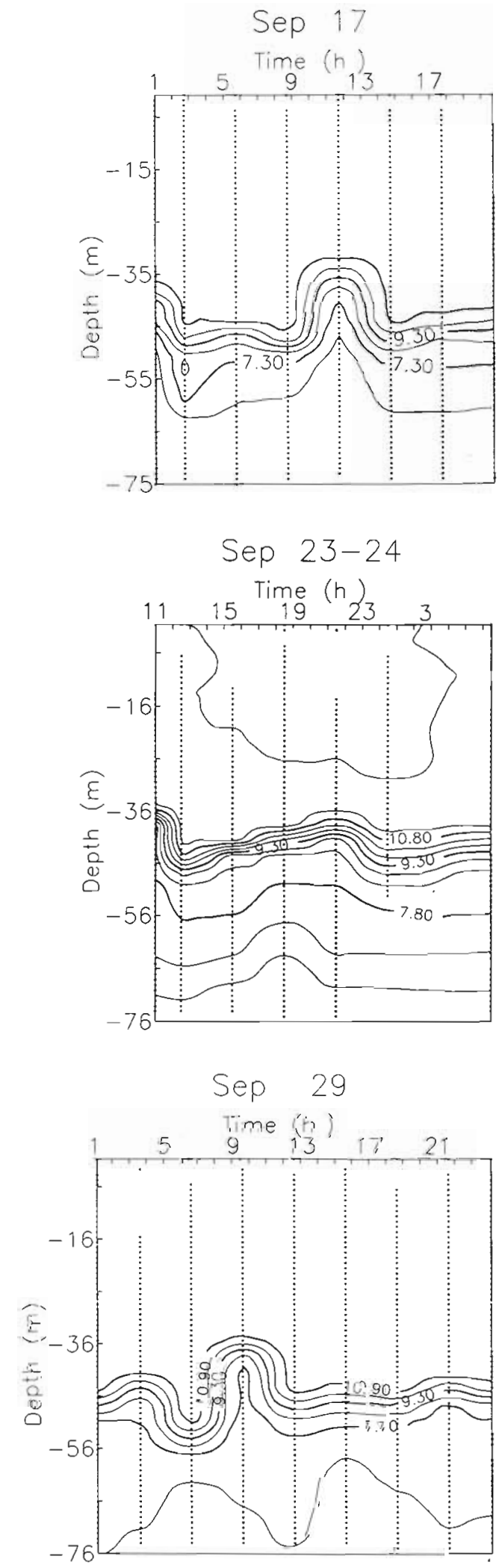
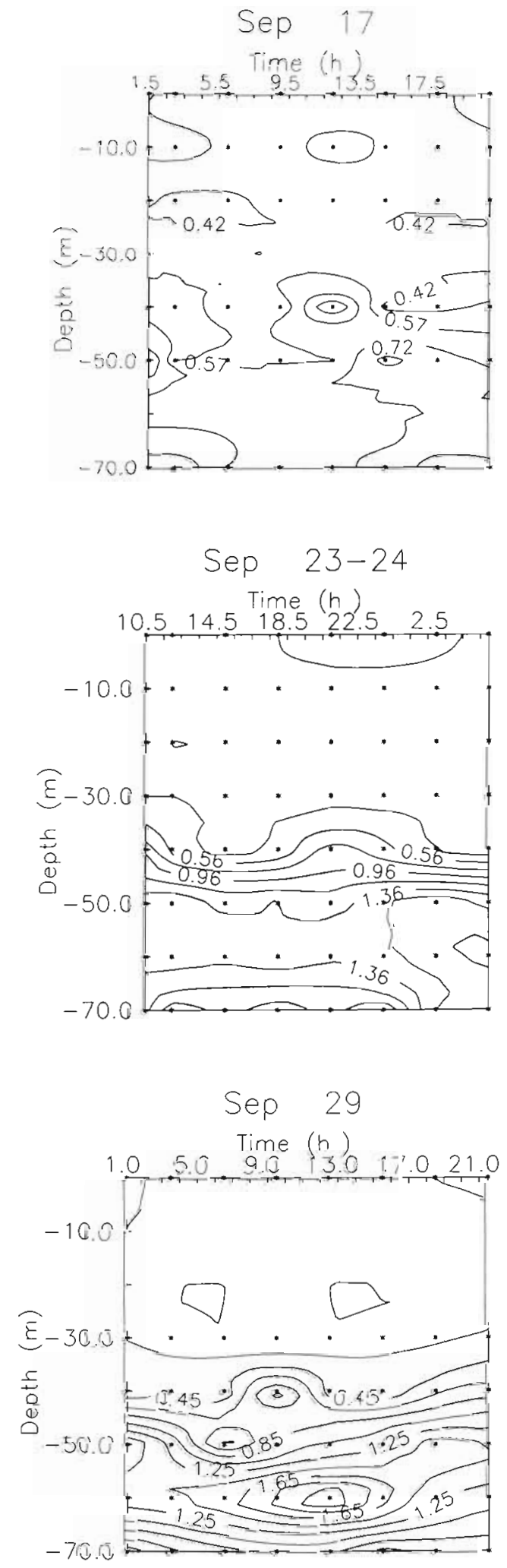

Fig. 2. Station profiles. Left column: temperature $\left({ }^{\circ} \mathrm{C}\right)$ as a function of depth and time of the 3 diel cycles at Station $R($ Sep 17,1987$)$ and Station P (Sep 23-24 and 29, 1987). Right column: cell numbers of Synechococcus spp. $\left(\times 10^{4} \mathrm{ml}^{-1}\right.$; other conditions as in left column\} 


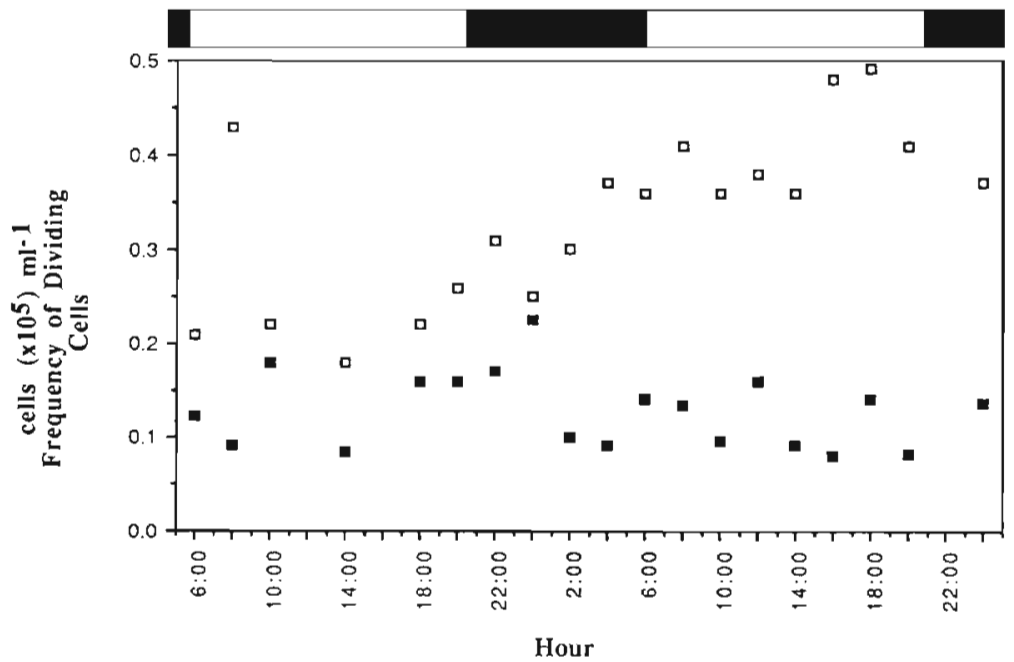

Fig. 3. Synechococcus spp. FDC () and cell number ( $\bullet$ at the water surface, Station R, Jun 21-22, 1987 Bar: time and duration of light and dark periods in FDC was a response to increasing suriace iliumination in this case. Alternatively, it is possible that a different, faster growing population of Synechococcus spp. was sampled on June 22 .

For all 3 diel cycles investigated in September, the FDCs were about half of those found in June and showed a highly significant diel pattern in the upper layers (Table 1, Fig. 4). The highest fraction of dividing cells occurred ca $14 \mathrm{~h}$ after sunrise. Populations of Synechococcus spp. living in and below the pycnocline had a lower FDC, and at Station $\mathrm{P}$ a diel pattern of dividing cells was not found or was not significant.

Low FDC combined with absence of a diel pattern of FDC has been interpreted as metabolic dormancy (e.g. Waterbury et al. 1986) based on observations of the division cycle of low latitude populations. But since the duration of division for the Alaska strain is so long (see next section) and probably results in a flattening of the diel FDC distribution, the absence of a marked pattern of dividing cells at low FDC might not necessarily indicate inactivity (see also 'Discussion').

\section{Culture observations}

For the isolated strain(s) of Synechococcus spp. from. the Gulf of Alaska, the duration of division was determined for 3 culture conditions (Table 2). The $13^{\circ} \mathrm{C}$ high-light cultures simulated in situ conditions in the mixed layer in September and the $8^{\circ} \mathrm{C}$ low-light culture in situ conditions at the pycnocline. The durations of division averaged $10.5 \mathrm{~h}$ with a narrow range in the experiments overall. Since no significant variation was observed within the range of culture conditions and growth rates, I consider the FDC-method to be accurate for calculating the growth rates of the populations living in both the mixed layer and the pycnocline.
The pattern of dividing celis observed in the cultures confirmed the field observation. In the culture with the lower growth rate, the FDC peaked around $14 \mathrm{~h}$ (as in the field) after the beginning of the light period. In the 2 cultures with high growth rates, however, the FDC stayed high throughout the day.

These observations on the pattern of dividing cells are partially confirmed for low-latitude strains. As commonly observed in the diel division cycles of Synechococcus spp. (e.g. Campbell \& Carpenter 1986a, Waterbury et al. 1986), the numbers of dividing cells peak at the end of the light period or beginning of the night. Also, Campbell \& Carpenter (1986a) observed in culture experiments that the peak of dividing cells was more pronounced for cultures growing at lower growth rates than for those growing at faster rates.

\section{Growth rates in the field}

Specific growth rates for the Synechococcus spp. population for each diel cycle and depth (Table 1) were calculated applying Eq. (1) and the $10.5 \mathrm{~h}$ duration of division. Maximum growth rates were calculated for June 21 and 22 in the surface with $0.57 \mathrm{~d}^{-1}$ and $0.78 \mathrm{~d}^{-1}$, respectively. In September, growth rates were much lower. The instantaneous growth rate averaged $0.25 \mathrm{~d}^{-1}$ in the surface layer and decreased with depth to about $0.16 \mathrm{~d}^{-1}$ at and below the pycnocline (Fig. 5). Cell numbers showed the opposite trend, with a high in abundance where growth rate was lowest (Fig. 5).

The high growth rates in June equalled the maximum growth rate measured in cultures with the strain isolated from Station P (at $8^{\circ} \mathrm{C}$ and 100 and $300 \mu \mathrm{mol}$ photons $\mathrm{m}^{-2} \mathrm{~s}^{-1}$ of $0.7 \mathrm{~d}^{-1}$, data not shown). Appa- 

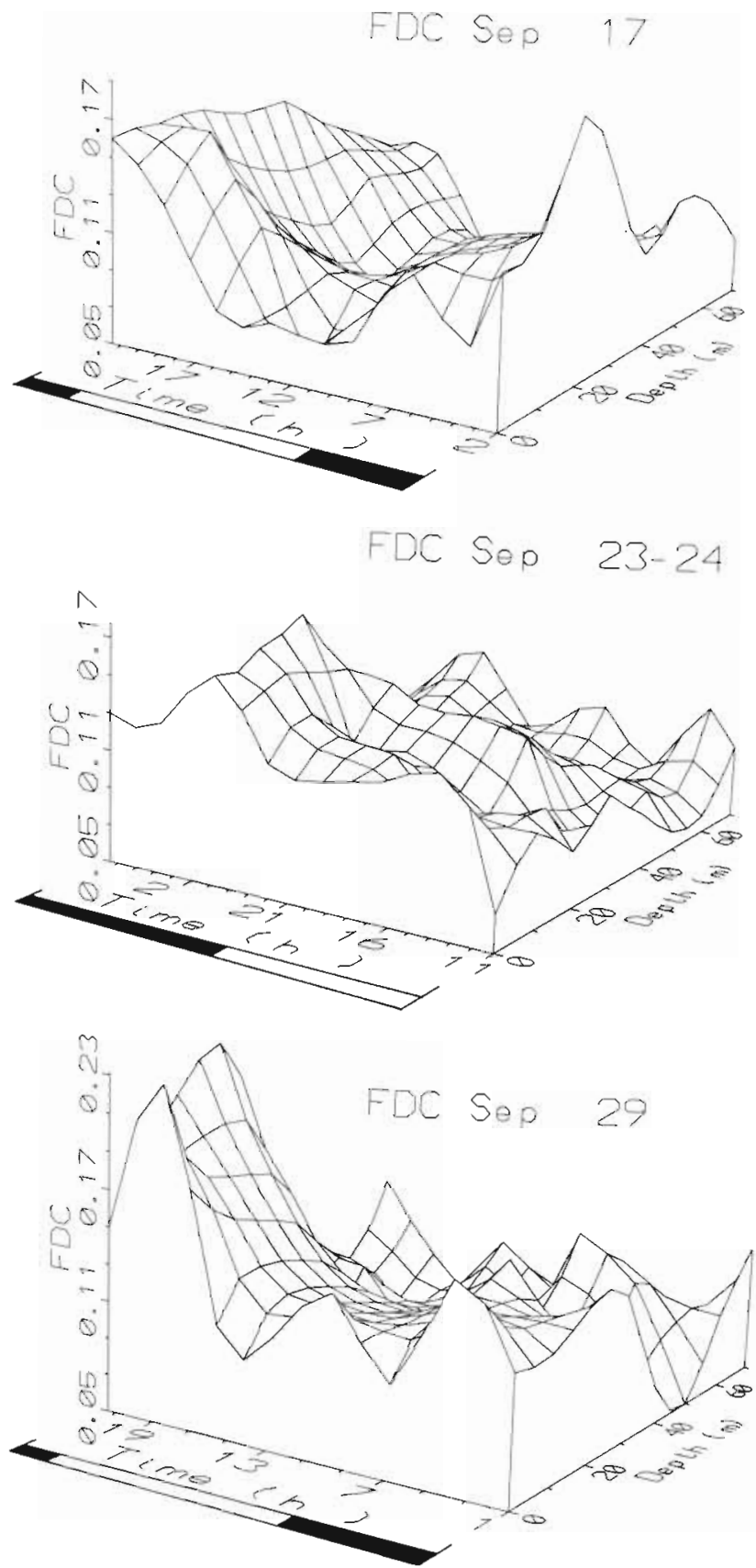

Fig. 4. Three-dimensional graphs of FDC as a function of depth and time of the 3 diel cycles at Station R (Sep 17, 1987) and Station P (Sep 23-24 and 29, 1987). Sampling for each diel cycle commenced at different day times. Bar: time and duration of light and dark periods

rently, in June the Synechococcus spp. population was growing at or near this maximum growth rate. Additionally, the estimates of cyanobacteria growth rates calculated using the FDC method are in agreement with results obtained in dilution and inhibitor experiments conducted by M. R. Landry (Univ. of Hawaii, pers. comm.) during the same SUPER cruises.
Table 2. Synechococcus spp. Duration of division of Subarctic Pacific strain(s) in laboratory experiments carried out under 3 culture conditions ( $n=1$ for each experiment)

\begin{tabular}{|c|c|c|}
\hline $\begin{array}{l}\text { Culture condition } \\
\text { (temperature, }{ }^{\circ} \mathrm{C} \text {; } \\
\text { Photon fluence rate, } \\
\text { umol } \mathrm{m}^{-2} \mathrm{~s}^{-1} \text { ) }\end{array}$ & $\begin{array}{l}\text { Growth rate } \\
\qquad\left(d^{-1}\right)\end{array}$ & $\begin{array}{c}\text { Duration of } \\
\text { division (h) } \\
\text { (95\% conf.interval) }\end{array}$ \\
\hline $13 ; 300$ & 0.46 & $11.7(2)$ \\
\hline $13 ; 100$ & 0.55 & $9.4(1.7)$ \\
\hline $8 ; 25-30$ & 0.32 & $10.3(3)$ \\
\hline
\end{tabular}

\section{DISCUSSION}

\section{Assumptions}

Because of the importance of the stated assumptions for the application of the FDC-method they will be briefly discussed here.

(1) All cells in the population are active. Because the Subarctic Pacific is replete with macronutrients and light is sufficient to allow growth throughout the mixed layer including the pycnocline (e.g. Table 2), there is no obvious reason to expect any part of the Synechococcus population to be inactive. More importantly, the field population is subject to grazing $\left(0.2\right.$ to $0.4 \mathrm{~d}^{-1}$, applying dilution and inhibitor techniques; M. R. Landry, Univ. of Hawaii, pers. comm.). Under grazing pressure, inactive cells would be highly selected against and would not likely be a significant fraction of the population.

(2) Duration of division is the same for all cells in the population. Differences in duration of division within a population can be caused by both environmental factors and inherent genetic variability. Environmental variability was addressed in the culture experiments and found to be negligible. That the cultured populations were true representatives of the field populations is an assumption that cannot be tested, but as such pervades any physiological experiments using cultured material. But since the Synechococcus spp. examined here in lab cultures were not clones, the cultured population was not purposefully deprived of genetic variability. Consequently, the duration of division found in the culture experiments very likely reflected the true average of the field population within the $95 \%$ confidence interval.

(3) Grazing pressure on dividing and on single cells is equal. Microscopic observations of the micrograzer community at Station $P$ revealed a wide variety of heterotrophic nanoflagellates and ciliates with ingested Synechococcus cells. Gonzalez et al. (1990) investigated size-specific grazing by heterotrophic nanoflagellates and found no relationship between prey size and clearance rate for bacteria greater than 
Cell Number $\left(\times 10^{4} / \mathrm{ml}\right)$

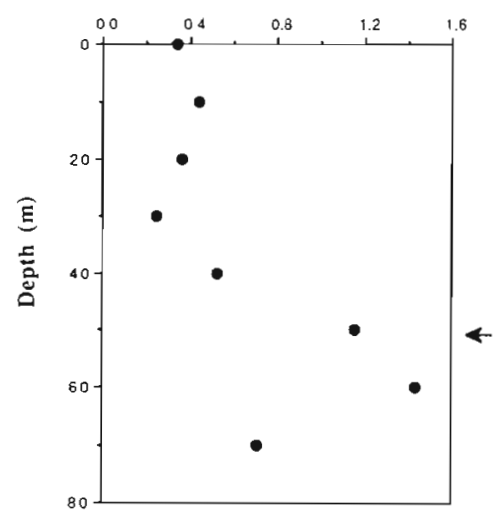

$\mu(1 / d)$

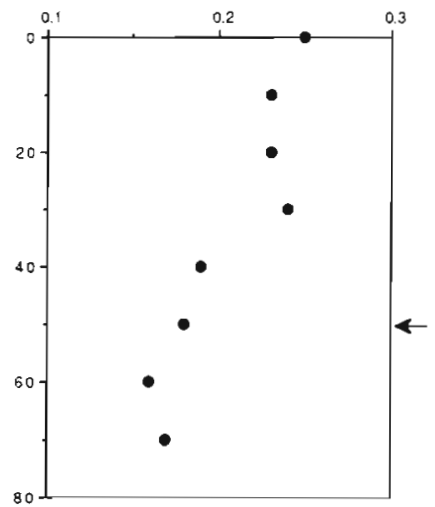

Fig. 5. Synechococcus spp. Average cell number and instantaneous growth rate $\left(\mu, \mathrm{d}^{-1}\right)$, Sep 1987. Stations P and R, as a function of water depth. Means of all 3 diel cycles in Sep 1987. Arrows: average $1 \%$ light level
$0.6 \mu \mathrm{m}$ including enteric bacteria (around $1 \mu \mathrm{m}$ in size, comparable to Synechococcus). For ciliates, Fenchel (1986) showed that the predalor-prey size reldionships followed a general 1:10 ratio. Because the micrograzer community at Station $\mathrm{P}$ included a wide size-spectrum of oligotrichous ciliates, a discrepancy in grazing rates on single versus paired cells is not to be expected.

There is evidence that some strains of marine Synechococcus spp. arrest in doublet stage during the night (Armbrust et al, 1989) and it was suggested that in this case the FDC method is not applicable (Chisholm et al. 1986). However, it should be noted that the duration of division is mainly a calibration factor that correlates frequency of dividing cells intregrated over one diel cycle with growth rate for each strain under investigation. In the case where the same strains as investigated in the field are cultured and the duration of division is determined under simulated in situ conditions, the fact that the duration of division is not constant throughout the day becomes irrelevant. One strain should exhibit the same division patterns in culture as in the field.

\section{Abundance and growth rates}

It is commonly thought that the distribution of the marine Synechococcus group in the world oceans correlates with surface temperatures, with the fewest cells occurring in polar waters where temperatures remain below $5^{\circ} \mathrm{C}$ throughout the year and highest abundance in tropical waters (Murphy \& Haugen 1985, Marchant et al. 1987). On the other hand, there is evidence pointing to other factors important in determining abundance such as differences in nutrient availability, grazing, differences in physiological types of the cyanobacteria and interspecific competition (Waterbury et al. 1986 , Shapiro \& Haugen 1988, Olson et al. 1990). However, growth rates and productivity of the Synechococcus spp. investigated so far indicate a strong correlation with temperature. In productivity experiments in Woods Hole Harbor (Woods ilole, MÁ), Waterbury et al. (1986) measured the lowest ${ }^{14} \mathrm{C}$-uptake at $13^{\circ} \mathrm{C}$ and the highest at $20^{\circ} \mathrm{C}$. In culture experiments with phycoerythrincontaining strains isolated from lower latitudes, Campbell \& Carpenter (1986a) found that growth was either low $\left(\mu=0.10 \mathrm{~d}^{-1}\right.$ and $\left.0.25 \mathrm{~d}^{-1}\right)$ or did not occur at $15^{\circ} \mathrm{C}$ and was most rapid at $25^{\circ} \mathrm{C}$. Attempts to grow the open ocean strain WH 7803 at $8^{\circ} \mathrm{C}$ have failed (Booth et al. 1988, Shapiro \& Haugen 1988).

Cell numbers observed in June and September in the Gulf of Alaska were in the range of cell numbers found by other authors in these latitudes (Murphy \& Haugen 1985 , Booth 1988). The higher cell numbers reported in June in the surface $\left(8^{\circ} \mathrm{C}\right)$ compared to September in the surface $\left(12^{\circ} \mathrm{C}\right)$, however, are again an indication that temperature is not the sole factor in determining abundances of the cyanobacteria. But the calculated growth rates of Synechococcus spp. in the Gulf of Alaska in June at Station $R$ in the surface waters (ca 1 doubling $\mathrm{d}^{-1}, 8^{\circ} \mathrm{C}$ ) and the high growth rate in culture experiments at $8^{\circ} \mathrm{C}$ and $13{ }^{\circ} \mathrm{C}$ point to an unusual temperature tolerance of Synechococcus spp. thriving in the Subarctic Pacific.

Another indication of the different physiology of the strain(s) isolated from the Gulf of Alaska compared to other marine strains from lower latitudes is the $10.5 \mathrm{~h}$ duration of division. This is considerably Ionger than values found by Campbell \& Carpenter (1986a) for several phycoerythrin-containing marine synechococcus spp. strains isolated from tropical and subtropical seas, which averaged $3 \mathrm{~h}$ above $15^{\circ} \mathrm{C}$ with specific growth rates exceeding $0.4 \mathrm{~d}^{-1}$

According to culture data (Neuer \& Garcia-Pichel unpubl.), growth was clearly suboptimal in September (ca $0.25 \mathrm{~d}^{-1}$ vs a maximal measured $0.7 \mathrm{~d}^{-1}$ ). Macronutrients are abundant, and the mean daily light levels in the mixed layer in both June (around $200 \mathrm{umol}$ photons $\mathrm{m}^{-2} \mathrm{~s}^{-1}$ ) and September (between 50 and $200 \mathrm{\mu mol}$ 
photons $\mathrm{m}^{-2} \mathrm{~s}^{-1}$ ) are sufficient for optimal growth. It is likely then that the cyanobacteria were limited by a micronutrient. In light of the recent controversy regarding the role of iron as a growth limiting factor of phytoplankton in the Subarctic Pacific (Martin et al. 1989), iron is a candidate to have limited the growth of Synechococcus spp. Cyanobacteria have a higher metabolic need for iron, especially when nitrate is the nitrogen source, than other oceanic phytoplankton (Carr \& Wyman 1986). An iron concentration of $10 \mathrm{nM}$ limited the oceanic Synechococcus strain WH7803 (Brand 1983), whereas the concentrations of iron that Martin et al. (1989) found in the Subarctic Pacific are far lower (between 0.05 to $0.06 \mathrm{nmol} \mathrm{kg}^{-1}$ in the mixed layer at Station P, measured Aug 5, 1987). It is unlikely that the Alaska strain has this iron requirement especially since ammonium is the preferred nitrogen source of the phytoplankton in the Subarctic Pacific (Wheeler \& Kokkinakis 1990 ) but iron limitation has to be considered.

Levels of cell abundance not only reflect specific responses of growth rates to environmental conditions, but are also influenced by the balance between rates of growth and loss. The constant level of cell abundance observed throughout the daily cycles in June in the surface and in September in the euphotic zone indicates that growth rates were readily matched by loss rates on short periods. It is most likely that grazing was the major loss factor since sedimentation of the cells is negligible and advection would not account for a gradual loss of cells. Grazing could also account for the net decrease in cell number between Sep 23 and Sep 29 in the mixed layer at Station $\mathrm{P}$ (Table 1) since growth rates did not decrease. In microscopic samples from Stations R and P, I observed numerous ciliates and heterotrophic flagellates with ingested cells of Synechococcus spp. Campbell \& Carpenter (1986b) and Iturriaga \& Mitchell (1986) stated that a diverse assemblage of microheterotrophs is capable of grazing a considerable fraction of the daily production of the Synechococcus spp., in some cases completely balancing the growth of the cyanobacteria. I also found fecal pellets of copepods containing a great number of Synechococcus spp. Although it is not clear whether these cells were ingested directly or were in the guts of other prey items (Johnson et al. 1982), fecal pellets containing the cyanobacteria could mediate their flux out of the mixed layer.

The accumulation of Synechococcus spp. in and below the pycnocline could occur as a result of reduced grazing pressure due to the relatively low numbers of grazers found in conjunction with the Synechococcus spp. maximum (Fig. 1b). The cyanobacteria-cell maximum was also observed in August 1984 during SUPER cruise II (Booth 1988) and is commonly found in areas of lower latitudes, as observed for example by Iturriaga \& Mitchell (1986) for the North Pacific Gyre.
The high abundance and growth rate of Synechococcus spp. in the surface in June and the accumulation of cells observed at the end of June and throughout September in the pycnocline fit with the notion of a spring 'bloom' period for the cyanobacteria, followed by a decline into a stage of slower growth in summer. However, it is possible that the high growth rates found in June do not necessarily represent a seasonal average since they are based on only $1.5 \mathrm{~d}$ of sampling.

\section{Contribution of Synechococcus spp. to total phytoplankton}

Since production and biomass data of total phytoplankton are available, it is possible to calculate the contribution of Synechococcus spp. to total phytoplankton for both months. In comparing production values calculated for the cyanobacteria with those for total phytoplankton, however, one should keep in mind that the rates were calculated using different methods, FDC and ${ }^{14} \mathrm{C}$-uptake rates, respectively. Unlike the ${ }^{14} \mathrm{C}$-based production measurements, the FDC technique does not require incubation and thus is not subject to the possible artifacts that arise from this manipulation of the plankton community.

The calculated Synechococcus spp. growth rates (Tables 1 \& 3) were in almost all cases lower than the growth rates of the entire phytoplankton community. In June near the surface, while the growth rate of phytoplankton was $1.1 \mathrm{~d}^{-1}\left(=1.6\right.$ doublings $\left.\mathrm{d}^{-1}\right)$, Synechococcus spp. grew at $0.57 \mathrm{~d}^{-1}\left(=0.8\right.$ doubling $\left.\mathrm{d}^{-1}\right)$. In September near the surface at both Stations $R$ and $P$, the phytoplankton was growing at about $0.7 \mathrm{~d}^{-1}(=1$ doubling $\mathrm{d}^{-1}$ ) and Synechococcus spp. only at $0.24 \mathrm{~d}^{-1}$ $\left(=0.4\right.$ doubling $\left.\mathrm{d}^{-1}\right)$. Near the $1 \%$ light depths in September, the difference in growth rates between both groups narrowed $\left(0.23 \mathrm{~d}^{-1}\right.$ versus $0.16 \mathrm{~d}^{-1}$ at Station P 50 m; $0.1 \mathrm{~d}^{-1}$ versus $0.21 \mathrm{~d}^{-1}$ at Station $\mathrm{R} 60 \mathrm{~m}$ ).

The cyanobacteria comprised $21 \%$ of total phytoplankton carbon and $8 \%$ of phytoplankton production in June near the surface. The results for the depthspecific comparison in September are shown in Fig. 6 for Station R, and in Fig. 7 for Station P. The overall contribution to total phytoplankton carbon and to total primary production was low in the surface, but increased with depth. The highest contribution was at Station $\mathrm{R}$ at the $1 \%$ light depth. As a fraction of integrated production $(0$ to $70 \mathrm{~m}$ ) averaged over all 3 diel cycles in September, Synechcoccus spp. only amounted to $4 \%$ (Table 3 ).

As a result of the lower specific growth rate of the cyanobacteria, Synechococcus spp. contributed comparatively less to total productivity than to total phytoplankton carbon. Thus, the importance of the cyano- 


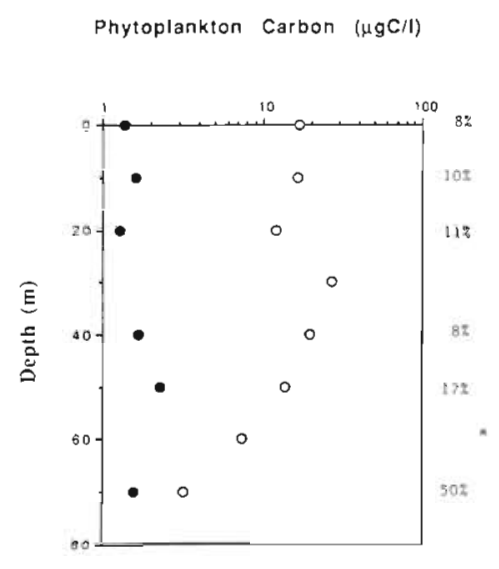

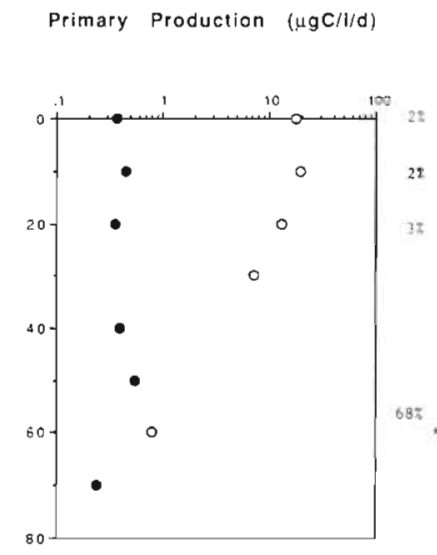

September, Station R
Fig. 6. Synechococcus spp. Comparison to total phytoplankton ( $O$ ) in terms of cell carbon and primary productivity from 1 to $70 \mathrm{~m}$ water depth at Stations R on Sep 17, 1987. Percentages depict the contribution of Synechococcus spp. to total phytoplankton for each depth. Stars: $1 \%$ light level

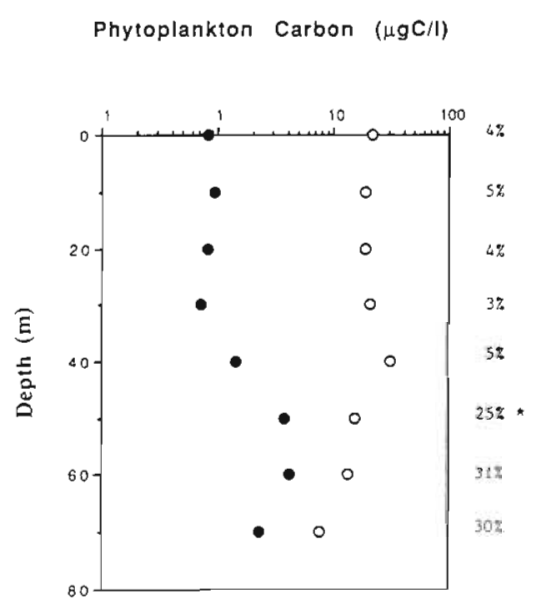

September, Station $P$

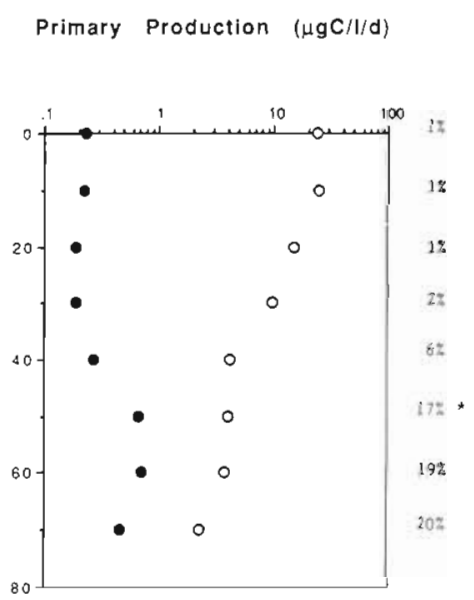

Fig. 7 Synechococcus spp. As in Fig. 6, but for Station P. Values averaged over diel cycles on Sep 23-24 and Sep 29. Values for total phytoplankton (o) taken from Sep 25 and 28

bacteria in the dynamics of the ecosystem of the Subarctic Pacific is less than indicated by relative abundance. This also implies that at a constant level of phytoplankton biomass, the loss rates of the Synechococcus population are smaller than those for the phytoplankton community as a whole.

The increase of the relative contribution of Synechococcus spp. to total primary production with depth is confirmed by many workers for lower latitudes and is interpreted as indicating low light saturation of growth (e.g Glover et al. 1986, Prézelin et al. 1986). Although in September the relative contribution to primary production increased with depth, growth rates of Synechococcus spp. in the mixed layer were higher than at the pycnocline. Thus, the high percentage of contribution does not reflect a low light saturation of growth but is due to the high cell number of Synechococcus spp. and the low production of total phytoplankton in that depth interval.

Table 3 shows the average growth rates of marine
Synechococcus spp. populations and their contribution to overall primary production in oceans of lower latitude in comparison to the results found for the Subarctic Pacific. With the exception of findings by Prézelin et al. (1987), ${ }^{14} \mathrm{C}$-uptake measurements of the size fraction containing cyanobacteria give higher estimates of growth rate than those obtained by single cell techniques. Size-fractionation can cause overestimation of growth rates and consequently also of relative contribution to primary production because of contamination with other phototrophic cells in the same size-range. But with the data available, the contribution of Synechococcus spp. to total primary production in the Gulf of Alaska appears to be within the range of values observed for lower latitudes. The greatest contribution, however, is restricted to a seasonal or possibly short term 'bloomperiod and local maxima in the water column. Also. growth rates from other oceanic regions estimated by applying single cell techniques agree well with the maximum growth rates found for the Synechococcus spp. 
Table 3. Synechococcus spp. Comparison of growth rates and contribution to total phytoplankton productivity in different oceans. A wide variety of methods were applied

\begin{tabular}{|c|c|c|c|}
\hline Site & Growth rate $\left(\mu, d^{-1}\right)$ & $\%$ Primary production & Source \\
\hline $\begin{array}{l}\text { Northwest Atlantic } \\
\text { summer, euphotic zone }\end{array}$ & NA & $6,25,46^{\mathrm{c}}$ & Glover et al. (1986) \\
\hline $\begin{array}{l}\text { Northwest Atlantic } \\
\text { Apr }\end{array}$ & $\begin{array}{l}0.7 \text { (average) }^{\mathrm{b}} \\
1.5 \text { (average) }^{\mathrm{a}}\end{array}$ & $\begin{array}{l}26-57 \text { (above } 30 \mathrm{~m})^{\mathrm{a}} \\
50-100(\text { below } 30 \mathrm{~m})^{\mathrm{a}}\end{array}$ & Iturriaga \& Marra (1988) \\
\hline $\begin{array}{l}\text { North Pacific Gyre } \\
\text { spring, mixed layer } \\
105 \mathrm{~m}\end{array}$ & $\begin{array}{l}1.3^{\mathrm{u}} \\
2.3^{\mathrm{d}}\end{array}$ & $\begin{array}{l}56^{\circ} \\
45^{\circ}\end{array}$ & Iturriaga \& Mitchell (1986) \\
\hline $\begin{array}{l}\text { Sargasso Sea } \\
\text { Feb, surface }\end{array}$ & $0.73^{\mathrm{c}}$ & NA & Campbell \& Carpenter (1986a) \\
\hline $\begin{array}{l}\text { Caribbean } \\
\text { Mar, surface }\end{array}$ & $0.56^{\mathrm{c}}$ & NA & Campbell \& Carpenter (1986a) \\
\hline $\begin{array}{l}\text { Tropical Pacific } \\
\text { spring, average }\end{array}$ & NA & $20-80^{\mathrm{a}}$ & Li et al (1983) \\
\hline $\begin{array}{l}\text { Tropical North Atlantic } \\
\text { Jul, chlorophyll-maximum }\end{array}$ & $0.15^{\mathrm{a}}$ & $60^{a}$ & Platt et al. (1983) \\
\hline $\begin{array}{l}\text { Northwest Atlantic } \\
\text { summer, euphotic zone }\end{array}$ & $\begin{array}{l}0.1-0.52^{\mathrm{d}} \\
0.27-0.83^{\mathrm{c}}\end{array}$ & $\begin{array}{l}\text { NA } \\
\text { NA }\end{array}$ & Prézelin et al. (1987) \\
\hline $\begin{array}{l}\text { Subarctic Pacific } \\
\text { Jun } 21, R, \text { surface } \\
\text { Jun 22, R, surface } \\
\text { Sep 17, R, 50-60 m } \\
\text { Sep 23-24, 29, P, } 50 \mathrm{~m} \\
\text { Sep, P and R, } 1-70 \mathrm{~m}\end{array}$ & $\begin{array}{l}0.57^{c} \\
0.78^{c} \\
0.21^{c} \\
0.16^{c} \\
0.21^{c}\end{array}$ & $\begin{array}{r}8^{\mathrm{c}} \\
\mathrm{NA} \\
68^{\mathrm{c}} \\
20^{\mathrm{c}} \\
4^{\mathrm{c}}\end{array}$ & This study \\
\hline
\end{tabular}

population in the Gulf of Alaska, although growth rates in September range in the lower end of the spectrum.

Acknowledgements. I am especially grateful to Karl Banse for advise and helpful discussions and to Ferran Garcia-Pichel for providing the enrichment culture of the Synechococcus spp. Beatrice Booth gave the idea to this study and made her laboratory and the data on total phytoplankton carbon available to me. Mike Landry provided me with the opportunity to participate in SUPER-IV (NSF grant OCE 8614401). I am grateful to Mary-Jane Perry for the use of the EPICS-V flow cytometer, John Baross for the use of the ZEISS epifluorescence microscope and Tim Cowles for the use of his computer facilities. Nick Welschmeyer shared his data on phytoplankton production. Comments by Ferran Garcia-Pichel, Tim Cowles, Charlie Miller and the anonymous reviewers improved the manuscript. The author was supported by a Fulbright-ITT fellowship during this study. This is contribution No. 1938 from the School of Oceanography, University of Washington, Seattle, USA.

\section{LITERATURE CITED}

Armbrust, E. V., Bowen, J. D., Olson, R. J., Chisholm, S. W. (1989). Effect of light on the cell cycle of a marine Synechococcusstrain. Appl. environ. Microbiol 55: 425-432
Banse, K. (1991). Iron availability, nitrate uptake, and exportable new production in the Subarctic Pacific. J. geophys. Res. 96: 741-748

Bolin, B., Degens, E. T., Duvigneaud, P., Kempe, S. (1977). The global biogeochemical carboncycle. In: Bolin, B., Degens, E. T., Kempe, S., Ketner, P. (eds) The global carbon cycle. Wiley, Chichester, p. 1-53

Booth, B. C. (1987). The use of autofluorescence for analyzing oceanic phytoplankton communities. Botanica mar 30: $101-108$

Booth, B. C. (1988). Vertical and temporal variation of phytoplankton from the subarctic Pacific, Station P. I. Size classes and major taxonomic groups. Mar Biol. 97: 275-286

Booth, B. C., Lewin, J., Lorenzen, C. J. (1988). Spring and summer growth rates of subarctic Pacific phytoplankton assemblages determined from carbon uptake and cell volumes estimated using epifluorescence microscopy. Mar. Biol. 98: 287-298

Brand. L. E., Sunda, W. G., Guillard, R. R. L. (1983). Limitation of marine phytoplankton reproductive rates by zinc, manganese and iron. Limnol. Oceanogr 28: 1182-1198

Campbell, L., Carpenter, E. J. (1986a). Diel patterns of cell division in marine Synechococcus spp. (Cyanobacteria): Use of the frequency of dividing cells technique to measure growth rate. Mar. Ecol. Prog. Ser. 32: 139-148

Campbell, L. Carpenter, E. J. (1986b). Estimating the grazing pressure of heterotrophic nanoplankton on Synechococcus 
spp. using the sea water dilution and selective inhibitor techniques. Mar Ecol. Prog. Ser. 33: 121-129

Castenholz, R. W., Waterbury, J. B. (1989). Cyanobacteria. In: Staley, J. T., Bryant, M. P., Pfennig N., Holt, J. G. (eds.) Bergey's manual of systematic bacteriology, Vol. III. Williams and Wilkins, Baltimore, p. 1710-1798

Carr, N. G., Wyman, M. (1986). Cyanobacteria: their biology in relation to the oceanic picoplankton. In: Platt, T., Li, W. K. W. (eds.) Photosynthetic picoplankton. Can. Bull. Fish. Aquat. Sci. 214: 159-204

Chisholm, S. W., Armbrust, E. V., Olson, R. L. (1986). The individual cell in phytoplankton ecology: cell cycle and application of flow-cytometry. In: Platt, T., Li, W. K. W (eds.) Photosynthetic picoplankton. Can. Bull. Fish. Aquat. Sci. 214: 343-369

Cuhel, R. L., Waterbury, J. B. (1984). Biochemical composition and short term nutrient incorporation patterns in a unicellular marine cyanobacterium, Synechococcus (WH 7803). Limnol. Oceanogr. 29: 370-374

Douglas, S. E., Carr, J. B. (1988). Examination of genetic relatedness of Marine Synechococcus spp. by using restriction fragment length polymorphism. Appl. environ. Microbiol. 54: $3071-3078$

Fahnenstiel, G. L., Scavia, D., Lang, G. A., Saylor, J. H., Miller, G. S., Schwab, D. J. (1988). Impact of inertial period waves on fixed-depth primary productivity estimates. J. Plankton Res. 10: 77-87

Fenchel, T (1986). Protozoan filter feeding. In: Corliss, J. O., Patterson, D. J. (eds.) Progress in protistology, Vol. 1 Biopress, Bristol, p. 65-113

Fleiss, J. L. (1981). Statistical methods for rates and proportions. Wiley, Chichester

Frost, B. W. (1987). Grazing control of phytoplankton stock in the open subarctic Pacific Ocean: a model assessing the role of mesozooplankton, particularly the large calanoid copepods Neocalanus spp. Mar. Ecol. Prog. Ser. 39: 49-68

Glover, H. E., Campbell, L., Prézelin, B. B. (1986). Contribution of Synechococcus spp. to size-fractioned primary productivity in three water masses in the Northwest Atlantic Ocean. Mar. Biol. 91: 193-203

Gonzalez, J. M., Sherr, E. B., Sherr, B. F. (1990). Size-selective grazing on bacterja by natural assemblages of estuarine flageliates and ciliates. Appl. environ. Microbiol. 56: $583-589$

Hagström, A., Larsson, U., Horstedt, P., Normark, S. (1979) Frequency of dividing cells, a new approach to the determination of bacterial growth rates in aquatic environments. Appl. environ. Microbiol. 37. 805-812

Iturriaga, R, Mitchell, B. G. (1986). Chroococcoid cyanobacteria: a significant component in the food web dynamics in the open ocean. Mar Ecol. Prog. Ser 28: 291-297

Iturriaga, R., Marra, J. (1988). Temporal and spatial variability of chroococcoid cyanobacteria Synechococcus spp. specific growth rates and their contribution to primary production in the Sargasso Sea. Mar. Ecol. Prog. Ser. 44: 175-181

Johnson, P. W., Sieburth, J. McN. (1979). Chroococcoid cyanobacteria in the sea: an ubiquituous and diverse phototrophic biomass. Limnol. Oceanogr 24: 228-235

Johnson, P. W., Huai-Suh, X., Sieburth, J. McN. (1982). The utilization of chroococcoid cyanobacteria by marine protozooplankters but not by calanoid copepods. Annls Inst. Océanogr., Paris 58: 297-308

This article was presented by D. M. Nelson, Corvallis, Oregon, USA
Li, W. K. W., Subba Rao, D. V., Harrison, W G., Smith, J. C., Cullen, J. J., Irwin, B., Platt, T (1983). Autotrophic picoplankton in the tropical ocean. Science 219: 292-295

Marchant, H. J., Davidson, A. T., Wright, S. W. (1987). The distribution and abundance of chroococcoid cyanobacteria in the Southern Ocean. Proc of the NIPR Symp. Pol. Biol. 1: $1-9$

Martin, J. H., Gordon, R. M., Fitzwater, S., Broenkow, W. W. (1989). VERTEX: phytoplankton/iron studies in the Gulf of Alaska. Deep Sea Res. 36: 649-680

McDuff, R. E., Chisholm, S. W. (1982). The calculation of in situ growth rates of phytoplankton populations from fractions of cells undergoing mitosis: a clarification. Limnol. Oceanogr. 27: 783-788

Miller, C. B., Frost, B. W., Booth, B., Wheeler, P. A., Landry, M. R. (1991). Ecological processes in the subarctic Pacific: iron-limitation cannot be the whole story. Oceanography 4: $71-78$

Murphy, L. S., Haugen, E. M. (1985). The distribution and abundance of phototrophic ultraplankton in the North Atlantic. Limnol. Oceanogr. 30: 47-58

Olson, R. J., Chisholm, S. W., Zettler, E. R., Armbrust, E. V (1990). Pigments, size, and distribution of Synechococcus in the North Atlantic and Pacific Oceans. Limnol. Oceanogr. 35: 45-58

Platt, T., Subba Rao, D. V., Irwin, B. (1983). Photosynthesis of picoplankton in the oligotrophic ocean. Nature, Lond. 301: $702-704$

Porter, K. G., Feig, Y. S. (1980). The use of DAPI for identifying and counting aquatic microflora. Limnol. Oceanogr 25: 943-948

Prézelin, B. B., Putt, M., Glover, H. E. (1986). Diurnal pattern in photosynthetic capacity and depth-dependent photosynthesis-irradiance relationships in Synechococcus spp. and larger phytoplankton in three water masses in the Northwest Atlantic Ocean. Mar. Biol. 91: 205-217

Prézelin, B. B., Putt, H. E., Campbell, L. (1987). Effects of light intensity and nutrient availability on diel patterns of cell metabolism and growth in populations of Synechococcus spp. Mar. Biol. 95: 469-480

Rippka, R., Deruelles, J., Waterbury, J. B., Herdman, M., Stanier, R. Y (1979). Generic assignments, strain histories and properties of pure cultures of cyanobacteria. J. Gen. Microbiol. 111. 1-61

Shapiro, L. P., Guillard, R. R. (1986). Physiology and ecology of the marine eucaryotic ultraplankton. In: Platt, T., Li, W. K. W (eds.) Photosynthetic picoplankton. Can. Bull. Fish. Aquat. Sci. 214: 371-389

Shapiro, L. P., Haugen, E. M. (1988). Seasonal distribution and temperature tolerance of Synechococcus in Boothbay Harbor, Maine. Estuar coast. Shelf Sci. 26: 517-525

Waterbury, J. B., Watson, S. W, Gujllard, R. R. L., Brand, L. E. (1979). Widespread occurrence of a unicellular, marine, planktonic cyanobacterium. Nature, Lond. 277: 293-294

Waterbury, J. B., Watson, S. W., Valois, F. W., Franks, D. G. (1986). Biological and ecological characterization of the marine unicellular cyanobacterium Synechococcus. In: Platt, T., Li, W. K. W (eds.) Photosynthetic picoplankton. Can. Bull. Fish. Aquat. Sci. 214: 71-120

Wheeler, P. A. . Kokkinakis, S. (1990). Ammonium recycling limits nitrate use in the oceanic subarctic Pacific. Limnol. Oceanogr. 35: 1.267-1278

Manuscript first received: November 8, 1991

Revised version accepted: April 14, 1992 